\title{
Inhibition of Suicidal Erythrocyte Death by Volasertib
}

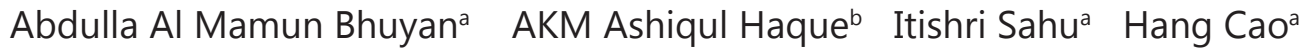 \\ Michael S.D. Kormann ${ }^{b} \quad$ Florian Lang ${ }^{c, d}$
}

${ }^{a}$ Department of Internal Medicine III, Eberhard-Karls-University of Tuebingen, bepartment of Pediatrics I, Pediatric Infectiology and Immunology, Translational Genomics and Gene Therapy in Pediatrics, University of Tuebingen, Tuebingen, 'Department of Molecular Medicine II, Medical Faculty, Heinrich Heine University, Duesseldorf, dDepartment of Physiology I, Eberhard-Karls-University of Tuebingen, Germany

\section{Key Words}

Phosphatidylserine - Eryptosis; energy depletion - Oxidative stress - Hyperosmotic shock • Ionomycin $•$ Calcium $\bullet$ Volasertib

\begin{abstract}
Background/Aims: The Polo-like kinase 1 (Plk1) inhibitor volasertib is used in the treatment of malignancy. Volasertib is partially effective by triggering suicidal death or apoptosis of tumor cells. Similar to apoptosis of nucleated cells, erythrocytes may enter suicidal cell death or eryptosis, which is characterized by cell membrane scrambling with phosphatidylserine translocation to the cell surface and by cell shrinkage. Stimulators of eryptosis include energy depletion, hyperosmotic shock, oxidative stress and excessive increase of cytosolic $\mathrm{Ca}^{2+}$ activity $\left(\left[\mathrm{Ca}^{2+}\right]_{i}\right)$. The present study explored, whether volasertib impacts on eryptosis. Methods: Human erythrocytes have been exposed to energy depletion (glucose withdrawal for 48 hours), hyperosmotic shock (addition of $550 \mathrm{mM}$ sucrose for 6 hours), oxidative stress (addition of $0.3 \mathrm{mM}$ tert-butylhydroperoxide [tBOOH] for $50 \mathrm{~min}$ ) or $\mathrm{Ca}^{2+}$ ionophore ionomycin $(1 \mu \mathrm{M}$ for $60 \mathrm{~min})$ in absence and presence of volasertib $(0.5-1.5 \mu \mathrm{g} / \mathrm{ml})$ and flow cytometry was employed to quantify phosphatidylserine exposure at the cell surface from annexin- $V$ binding, cell volume from forward scatter, $\left[\mathrm{Ca}^{2+}\right]_{\mathrm{i}}$ from Fluo3 fluorescence, reactive oxygen species from 2',7'-dichlorodihydrofluorescein diacetate (DCFDA) fluorescence and ceramide abundance utilizing antibodies. For comparison, annexin-V-binding and forward scatter were determined following a 48 hours exposure of human leukemic K562 cells in RPMI-1640 medium to volasertib. Results: Treatment with volasertib alone did not significantly modify annexin-V-binding or forward scatter in mature erythrocytes. Energy depletion, hyperosmotic shock, oxidative stress and ionomycin, all markedly and significantly increased the percentage of annexin-V-binding erythrocytes, and decreased the forward scatter. Volasertib significantly blunted the effect of energy depletion and hyperosmotic shock, but not of oxidative stress and ionomycin on annexin-V-binding. Volasertib did not significantly influence the effect of any maneuver on forward scatter. In K562 cells, volasertib enhanced annexin-V-binding and


decreased the forward scatter. Conclusions: Volasertib is a novel inhibitor of erythrocyte cell membrane scrambling following energy depletion and hyperosmotic shock, effects contrasting the stimulation of $\mathrm{K} 562$ cell apoptosis.

\section{Introduction}

The Polo-like kinase 1 (Plk1) inhibitor volasertib (BI6727) [1-10] has been successfully used in preclinical and clinical studies for the treatment of several malignancies [1, 2, 7-14] including acute myeloid leukaemia (AML) [2-9, 11, 15-20]. Volasertib is in part effective by triggering suicidal death or apoptosis of tumor cells $[1,7]$. Reported side effects of treatment with volasertib or combinations of volasertib with other cytostatic drugs include anemia $[12,13,21]$.

At least in theory, the anemia following volasertib treatment could result from stimulation of suicidal erythrocyte death or eryptosis [22,23], which is characterized by cell membrane scrambling with phosphatidylserine translocation to the cell surface [22]. Another hallmark of eryptosis is cell shrinkage [24]. Eryptosis could be stimulated by cell stress, e.g. by energy depletion [22], hyperosmotic shock [22], and oxidative stress [22]. Signaling mechanisms triggering eryptosis include increase of cytosolic $\mathrm{Ca}^{2+}$ activity $\left(\left[\mathrm{Ca}^{2+}\right]_{\mathrm{i}}\right)[22]$, ceramide [25],

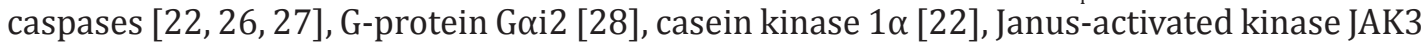
[22], protein kinase $C$ [22], and p38 kinase [22]. Signaling mechanisms inhibiting eryptosis include the kinases AMPK [22], cGMP-dependent protein kinase [22], MSK1/2 [29], PAK2 [22] and sorafenib/sunitinib sensitive kinases [22]. Eryptosis is stimulated by a myriad of xenobiotics [22, 29-83] and enhanced eryptosis is observed in a variety of clinical conditions including iron deficiency [22], dehydration [84], hyperphosphatemia [74], vitamin D excess [38], chronic kidney disease (CKD) [85-89] hemolytic-uremic syndrome [90], diabetes [91], hepatic failure [92, 93], malignancy [94, 95], arteritis [96], sepsis [97], sickle-cell disease [22], beta-thalassemia [22], Hb-C and G6PD-deficiency [22], Wilsons disease [98], as well as advanced age [99]. Eryptosis further increases following erythrocyte storage for transfusion [100].

The present study explored, whether volasertib impacts on eryptosis. To this end, human erythrocytes from healthy volunteers were exposed to volasertib in the absence and presence of energy depletion, hyperosmotic shock, oxidative stress, as well as $\mathrm{Ca}^{2+}$ loading. Phosphatidylserine surface abundance and cell volume were determined by flow cytometry. For comparison, the effect of volasertib was tested on annexin-V-binding and forward scatter of human leukemic K562 cells.

\section{Materials and Methods}

\section{Erythrocytes, solutions and chemicals}

Fresh Li-Heparin-anticoagulated blood samples were kindly provided by the blood bank of the University of Tübingen. The study is approved by the ethics committee of the University of Tübingen $(184 / 2003 \mathrm{~V})$. The blood was centrifuged at $120 \mathrm{~g}$ for $20 \mathrm{~min}$ at $21{ }^{\circ} \mathrm{C}$ and the platelets and leukocytescontaining supernatant was disposed. Erythrocytes were incubated in vitro at a hematocrit of $0.4 \%$ in Ringer solution containing (in $\mathrm{mM}$ ) $125 \mathrm{NaCl}, 5 \mathrm{KCl}, 1 \mathrm{MgSO}_{4}, 32 \mathrm{~N}$-2-hydroxyethylpiperazine-N-2-ethanesulfonic acid (HEPES; pH 7.4), 5 glucose, $1 \mathrm{CaCl}_{2}$, at $37^{\circ} \mathrm{C}$ for 48 hours. Where indicated, erythrocytes were exposed for 48 hours to glucose depleted Ringer solution, for 6 hours to hypertonic Ringer (addition of $550 \mathrm{mM}$ sucrose, Sigma Aldrich, Hamburg, Germany), for 50 minutes to the oxidant tert-butyl-hydroperoxide $(0.3 \mathrm{mM}$, Sigma Aldrich, Hamburg, Germany), or for 60 minutes to $\mathrm{Ca}^{2+}$ ionophore ionomycin $(1 \mu \mathrm{M}$, Merck Millipore, Darmstadt, Germany), each in the absence and presence of volasertib (MedChem Express, Princeton, USA).

K562 cell culture and treatments

The K562 human leukaemia cells (Sigma Aldrich, Hamburg, Germany) were cultured using RPMI-1640 medium (Biochrom GmbH, Berlin, Germany) supplemented with $2.0 \mathrm{~g} / \mathrm{l} \mathrm{NaHCO}_{3}$, without L-glutamine.The 


\section{Cellular Physiology Cell Physiol Biochem 2017;43:1472-1486 \begin{tabular}{l|l} 
and Biochemistry Published 10.1159/000481969 & $\begin{array}{l}\text { C) } 2017 \text { The Author(s). Published by S. Karger AG, Basel } \\
\text { www.karger.com/cpb }\end{array}$
\end{tabular}}

Al Mamun Bhuyan et al.: Volasertib-Induced Eryptosis

cells were cultured at $37^{\circ} \mathrm{C}$ in a moistened incubator with $5 \% \mathrm{CO}_{2}$. Where indicated, volasertib $(0.5-1.5 \mu \mathrm{g} /$ $\mathrm{ml}$ ) was added to the cell culture medium.

\section{Annexin-V-binding and forward scatter}

After incubation under the respective experimental condition, a $150 \mu \mathrm{l}$ cell suspension was washed in Ringer solution containing $5 \mathrm{mM} \mathrm{CaCl}_{2}$ and then stained with Annexin-V-FITC (1:200 dilution; ImmunoTools, Friesoythe, Germany) in this solution at $37^{\circ} \mathrm{C}$ for $15 \mathrm{~min}$ under protection from light. The annexin-Vabundance at the erythrocyte surface was subsequently determined on a FACS Calibur (BD, Heidelberg, Germany). Annexin-V-binding was measured with an excitation wavelength of $488 \mathrm{~nm}$ and an emission wavelength of $530 \mathrm{~nm}$. A marker (M1) was placed to set an arbitrary threshold between annexin-V-binding cells and control cells. The same threshold was used for untreated and volasertib treated erythrocytes. A dot plot of forward scatter (FSC) vs. side scatter (SSC) was set to linear scale for both parameters. The threshold of forward scatter was set at the default value of " 52 ".

\section{Intracellular $\mathrm{Ca}^{2+}$}

After incubation, erythrocytes were washed in Ringer solution and loaded with Fluo-3/AM (Biotium, Hayward, USA) in Ringer solution containing $5 \mathrm{mM} \mathrm{CaCl}_{2}$ and $5 \mu \mathrm{M}$ Fluo-3/AM. The cells were incubated at $37^{\circ} \mathrm{C}$ for $30 \mathrm{~min}$. $\mathrm{Ca}^{2+}$-dependent fluorescence intensity was measured with an excitation wavelength of $488 \mathrm{~nm}$ and an emission wavelength of $530 \mathrm{~nm}$ on a FACS Calibur. Afterwards, the geomean of the $\mathrm{Ca}^{2+}$ dependent fluorescence was determined.

Reactive oxygen species (ROS)

Oxidative stress was determined utilizing 2',7'-dichlorodihydrofluorescein diacetate (DCFDA). After incubation, a $150 \mu$ suspension of erythrocytes was washed in Ringer solution and stained with DCFDA (Sigma, Aldrich, Germany) in Ringer solution containing $10 \mu \mathrm{M}$ DCFDA. Erythrocytes were incubated at $37^{\circ} \mathrm{C}$ for $30 \mathrm{~min}$ in the dark and washed two times in Ringer solution. The DCFDA-loaded erythrocytes were resuspended in $200 \mu \mathrm{l}$ Ringer solution and ROS-dependent fluorescence intensity was measured at an excitation wavelength of $488 \mathrm{~nm}$ and an emission wavelength of $530 \mathrm{~nm}$ on a FACS Calibur (BD). Subsequently, the geomean of the DCFDA dependent fluorescence was determined.

\section{Ceramide abundance}

For the determination of ceramide, a monoclonal antibody-based assay was used. To this end, cells were stained for 1 hour at $37^{\circ} \mathrm{C}$ with $1 \mu \mathrm{g} / \mathrm{ml}$ anti ceramide antibody (clone MID 15B4, Alexis, Grünberg, Germany) in PBS containing $0.1 \%$ bovine serum albumin (BSA) at a dilution of 1:10. The samples were washed twice with PBS-BSA. The cells were stained for 30 minutes with polyclonal fluorescein isothiocyanate (FITC) conjugated goat anti-mouse IgG and IgM specific antibody (Pharmingen, Hamburg, Germany) diluted 1:50 in PBS-BSA. Unbound secondary antibody was removed by repeated washing with PBS-BSA. The samples were analysed by flow cytometric analysis with an excitation wavelength of $488 \mathrm{~nm}$ and an emission wavelength of $530 \mathrm{~nm}$. Finally, the geomean of the ceramide-dependent fluorescence was determined.

\section{Statistics}

Data are expressed as arithmetic means \pm SEM. As indicated in the figure legends, statistical analysis was made using ANOVA with Tukey's test as post-test. $\mathrm{n}$ denotes the number of different erythrocyte specimens studied. Since different erythrocyte specimens used in distinct experiments are differently susceptible to triggers of eryptosis, the same erythrocyte specimens have been used for control and experimental conditions.

\section{Results}

The present study explored, whether volasertib stimulates or interferes with eryptosis, the suicidal erythrocyte death. The two hallmarks of eryptosis, i.e. cell membrane scrambling and cell shrinkage were determined by flow cytometry. Phosphatidylserine exposing erythrocytes were identified utilizing annexin-V-binding to phosphatidylserine, cell shrinkage was quantified utilizing forward scatter. 


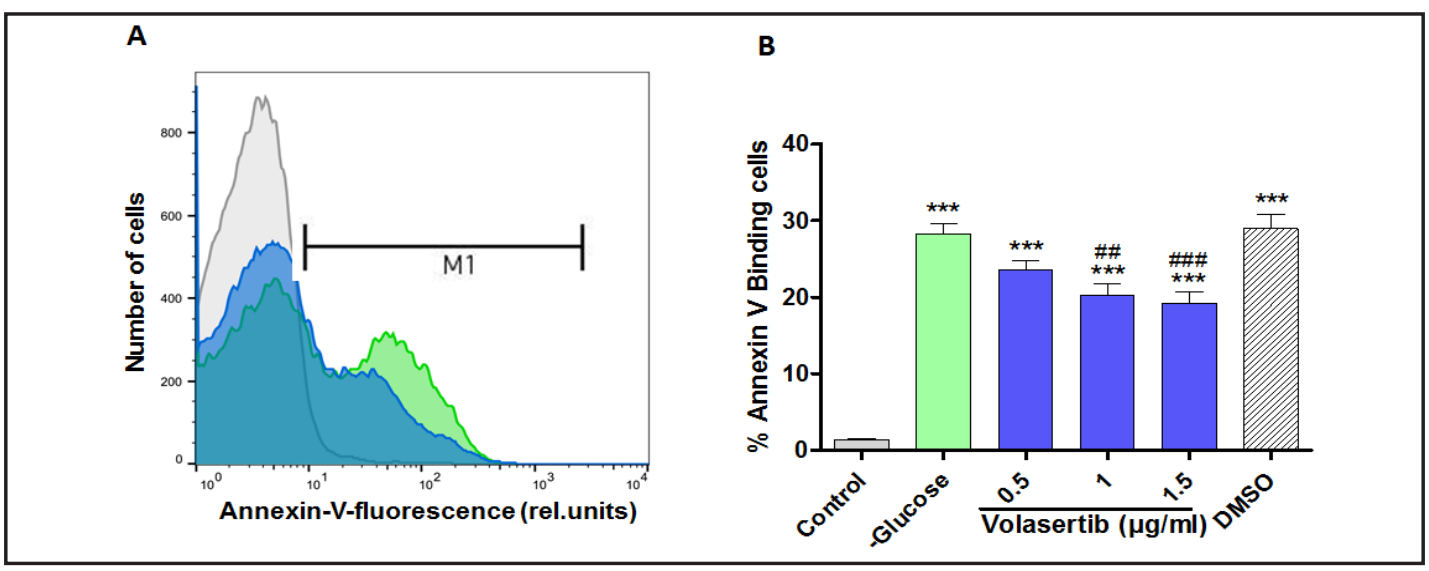

Fig. 1. Volasertib sensitivity of phosphatidylserine exposure following energy depletion. A. Original histograms of annexin-V-binding of erythrocytes following exposure for 48 hours to glucose containing Ringer solution (grey areas), Ringer solution without glucose (green areas) and Ringer solution without glucose and presence of volasertib $(1.5 \mu \mathrm{g} / \mathrm{ml})$ (blue areas). B. Arithmetic means \pm SEM $(\mathrm{n}=14)$ of the percentage of annexin-V-binding erythrocytes after a 48 hours treatment with Ringer solution with glucose (grey bar) or without glucose in the absence (green bar) and presence (blue bars) of volasertib $(0.5-1.5 \mu \mathrm{g} / \mathrm{ml})$. Striped bar is in absence of glucose and presence of DMSO. ${ }^{* * *}(\mathrm{p}<0.001)$ indicates significant difference from the

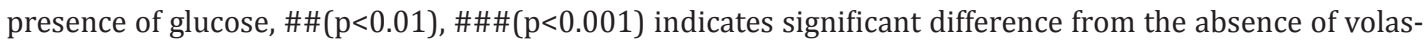
ertib (ANOVA).

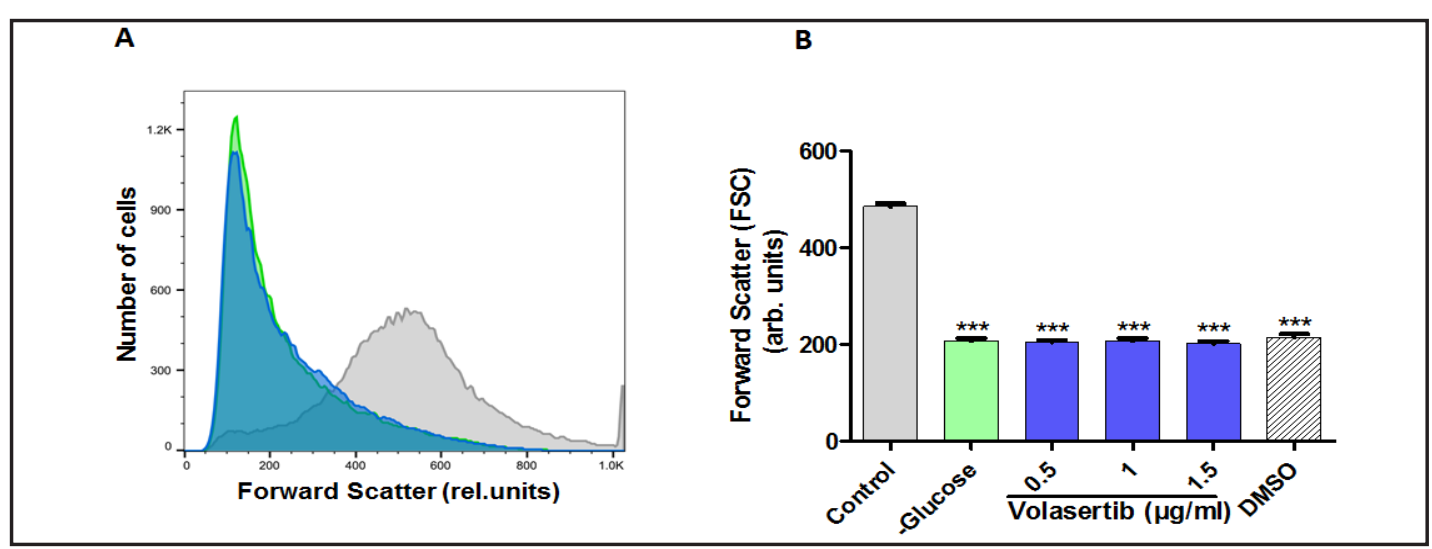

Fig. 2. Volasertib sensitivity of erythrocyte shrinkage following energy depletion. A. Original histograms of forward scatter of erythrocytes following exposure for 48 hours to glucose containing Ringer solution (grey areas), Ringer solution without glucose (green areas) and Ringer solution without glucose and presence of volasertib $(1.5 \mu \mathrm{g} / \mathrm{ml})$ (blue areas). B. Arithmetic means \pm SEM $(\mathrm{n}=14)$ of the erythrocyte forward scatter after a 48 hours treatment with Ringer solution with glucose (grey bar) or without glucose in the absence (green bar) and presence (blue bars) of volasertib (0.5-1.5 $\mathrm{g} / \mathrm{ml}$ ). Striped bar is in absence of glucose and presence of DMSO. ${ }^{* * *}(\mathrm{p}<0.001)$ indicates significant difference from the presence of glucose (ANOVA).

The percentage of human erythrocytes binding annexin- $\mathrm{V}$ after 48 hours incubation in standard, glucose containing, Ringer was low $(2.4 \pm 0.3 \%, \mathrm{n}=14)$ and not significantly modified by the presence of $1.5 \mu \mathrm{g} / \mathrm{ml}$ volasertib $(2.5 \pm 0.4 \%, \mathrm{n}=14)$. Thus, in standard glucose containing Ringer solution, volasertib did not appreciably modify erythrocyte cell membrane scrambling. As illustrated in Fig. 1, glucose removal was followed by a marked increase of the percentage of annexin-V-binding erythrocytes. The addition of volasertib $(0.5-1.5 \mu \mathrm{g} / \mathrm{ml})$ blunted the increase of the percentage of annexin-V-binding erythrocytes following glucose deprivation, an effect reaching statistical significance at 1 and $1.5 \mu \mathrm{g} / \mathrm{ml}$ volasertib. Nevertheless, even in the presence of volasertib, energy depletion significantly increased the percentage of phosphatidylserine exposing erythrocytes (Fig. 1). Volasertib thus partially blunted cell membrane scrambling following energy depletion. 
A

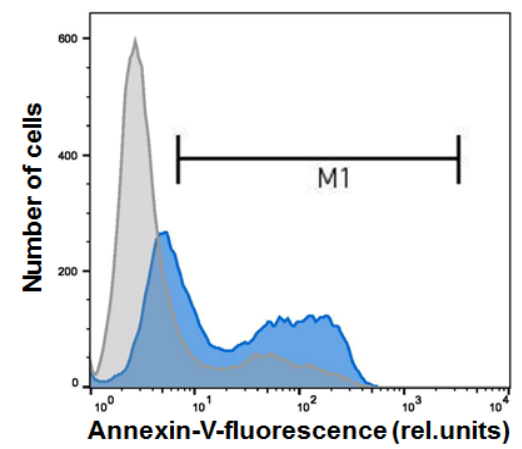

B

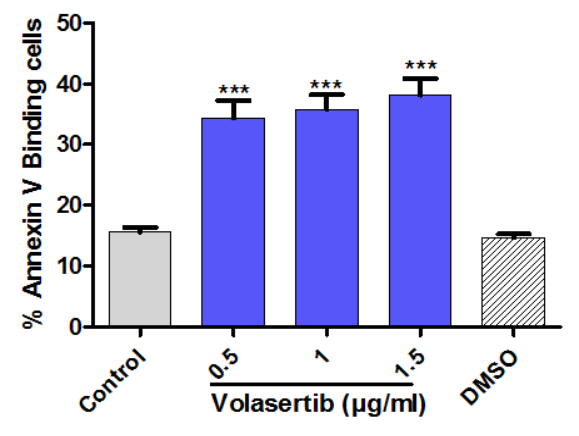

Fig. 3. Effect of Volasertib on phosphatidylserine exposure of K562 cells. A. Original histograms of annexinV-binding of K562 cells following exposure for 48 hours to RPMI 1640 medium without (grey area) and with presence of volasertib $(1.5 \mu \mathrm{g} / \mathrm{ml})$ (blue areas). B. Arithmetic means \pm SEM $(\mathrm{n}=10)$ of the percentage of annexin-V-binding K562 cells following incubation for 48 hours to RPMI 1640 medium without (grey bar) or with (blue bars) Volasertib $(0.5-1.5 \mu \mathrm{g} / \mathrm{ml})$. For comparison, the effect of the solvent DMSO is shown (Striped bar). ${ }^{* * *}(\mathrm{p}<0.001)$ indicates significant difference from the absence of volasertib (ANOVA).

A

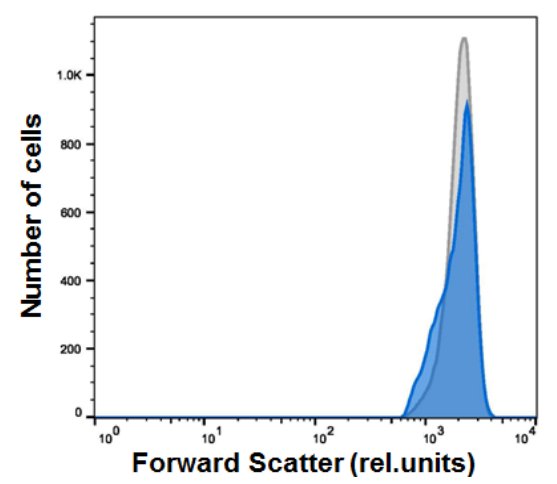

B

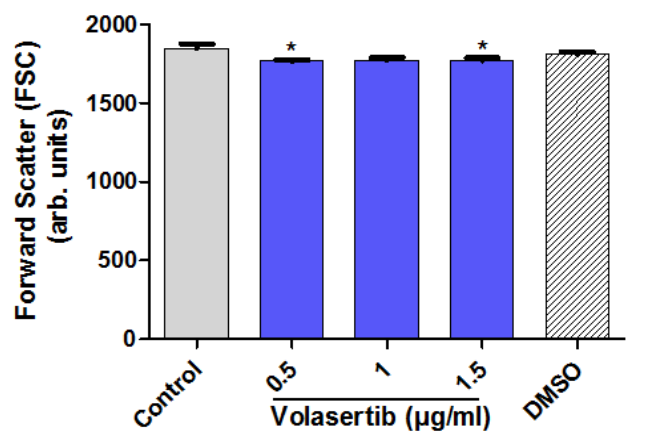

Fig. 4. Effect of Volasertib on K562 cell forward scatter (FSC). A. Original histograms of forward scatter reflecting cell volume of K562 cells following exposure for 48 hours to RPMI 1640 medium without (grey area) and with presence of volasertib $(1.5 \mu \mathrm{g} / \mathrm{ml})$ (blue areas). B. Arithmetic means \pm SEM $(\mathrm{n}=10)$ of K562 cell forward scatter (FSC) following incubation for 48 hours to RPMI 1640 medium without (grey bar) or with (blue bars) volasertib $(0.5-1.5 \mu \mathrm{g} / \mathrm{ml})$. For comparison, the effect of the solvent DMSO is shown (Striped bar). ${ }^{*}(\mathrm{p}<0.05)$ indicates significant difference from the absence of volasertib (ANOVA).

Erythrocyte forward scatter was, following a 48 hours exposure to Ringer solution in the presence of glucose, again similar in the absence $(517 \pm 6 \%, \mathrm{n}=14)$ and presence $(522$ $\pm 5.4 \%, \mathrm{n}=14)$ of volasertib $(1.5 \mu \mathrm{g} / \mathrm{ml})$. Accordingly, in standard glucose containing Ringer solution, volasertib did not appreciably modify erythrocyte volume. As illustrated in Fig. 2, a 48 hours exposure to glucose-depleted Ringer solution was followed by a marked decrease of forward scatter, reflecting erythrocyte shrinkage. The decline of erythrocyte forward scatter was, following a 48 hours exposure to Ringer solution in the absence of glucose, virtually identical in the absence and presence of volasertib $(0.5-1.5 \mu \mathrm{g} / \mathrm{ml})$. Accordingly, neither in energy repleted nor in energy depleted erythrocytes did volasertib significantly modify erythrocyte volume.

As volasertib did not, in contrast to previous observations in nucleated cells, significantly stimulate eryptosis, further experiments were performed exploring whether 


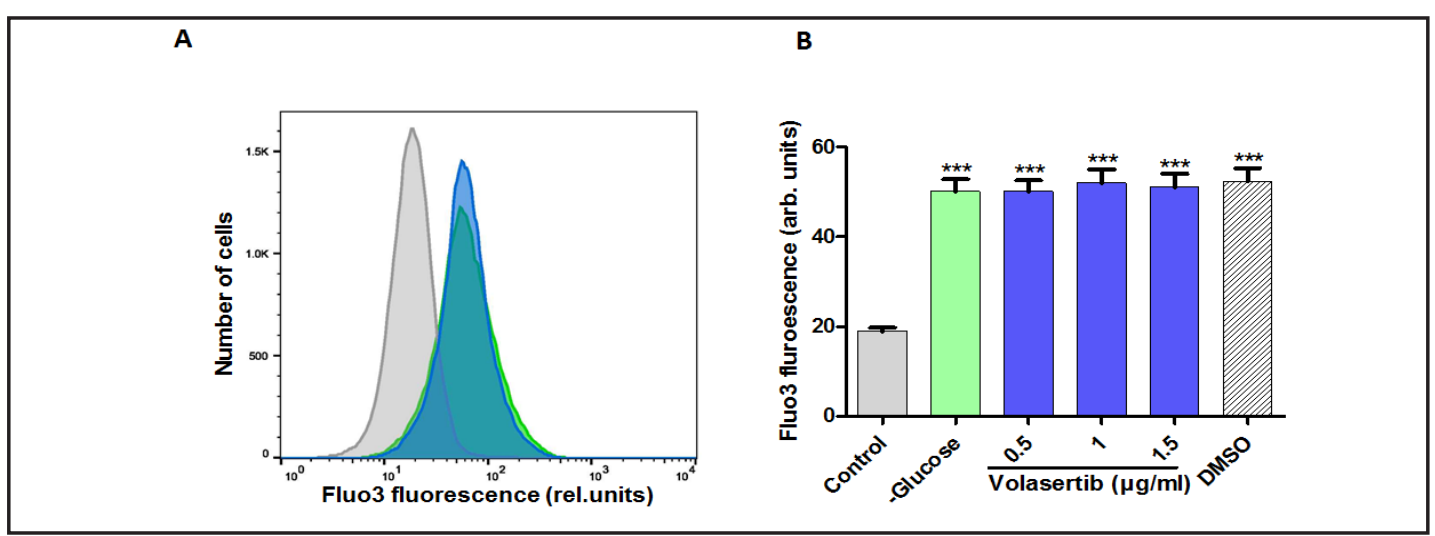

Fig. 5. Volasertib sensitivity of cytosolic $\mathrm{Ca}^{2+}$ activity following energy depletion. A. Original histograms of Fluo3 fluorescence reflecting cytosolic $\mathrm{Ca}^{2+}$ activity of erythrocytes following exposure for 48 hours to glucose containing Ringer solution (grey areas), Ringer solution without glucose (green areas) and Ringer solution without glucose and presence of volasertib $(1.5 \mu \mathrm{g} / \mathrm{ml}$ ) (blue areas). B. Arithmetic means \pm SEM ( $\mathrm{n}$ = 14) of erythrocyte Fluo3 fluorescence after a 48 hours treatment with Ringer solution with glucose (grey bar) or without glucose in the absence (green bar) and presence (blue bars) of volasertib (0.5-1.5 $\mu \mathrm{g} / \mathrm{ml})$. Striped bar is in absence of glucose and presence of DMSO. ${ }^{* * *}(\mathrm{p}<0.001)$ indicates significant difference from the presence of glucose.

volasertib stimulated apoptosis of K562 cells. As shown in Fig. 3, a 48 hours exposure to volasertib increased the percentage of phosphatidylserine exposing K562 cells at each of the concentrations applied $(0.5-1.5 \mu \mathrm{g} / \mathrm{ml})$ and as illustrated in Fig. 4, volasertib triggered cell shrinkage, an effect reaching statistical significance at $0.5 \mu \mathrm{g} / \mathrm{ml}$ and $1.5 \mu \mathrm{g} / \mathrm{ml}$ volasertib.

Further experiments addressed the influence of volasertib on cytosolic $\mathrm{Ca}^{2+}$ activity $\left(\left[\mathrm{Ca}^{2+}\right]_{\mathrm{i}}\right)$, which was estimated from Fluo3 fluorescence. As illustrated in Fig. 5, a 48 hours exposure to glucose depleted Ringer solution was followed by a marked significant increase of $\left[\mathrm{Ca}^{2+}\right]_{\mathrm{i}}$ both, in the absence and presence of volasertib. The addition of volasertib (0.5-1.5 $\mu \mathrm{g} / \mathrm{ml})$ did not significantly modify $\left[\mathrm{Ca}^{2+}\right]_{\mathrm{i}}$ in erythrocytes without or with energy depletion.

Reactive oxygen species (ROS) was determined utilizing 2',7'-dichlorodihydrofluorescein diacetate (DCFDA). After 48 hours incubation in standard glucose containing Ringer, the ROS was similar in the absence $(19.07 \pm 0.64, \mathrm{n}=5)$ and presence $(18.63 \pm 0.46, \mathrm{n}=5)$ of $1.5 \mu \mathrm{g} /$ $\mathrm{ml}$ volasertib. As illustrated in Fig.6, removal of glucose was followed by a marked significant increase of DCFDA fluorescence in the absence and presence of volasertib $(1.5 \mu \mathrm{g} / \mathrm{ml})$. The addition of volasertib did not significantly modify DCFDA fluorescence following glucose depletion.

The abundance of ceramide at the erythrocyte surface was quantified utilizing specific antibodies. The abundance of ceramide was similar following a 48 hours incubation in standard glucose containing Ringer $(10.11 \pm 0.24, \mathrm{n}=5)$ and in glucose depleted Ringer without $(10.1 \pm 0.2, \mathrm{n}=5)$ and with $(9.8 \pm 0.2, \mathrm{n}=5)$ addition of volasertib.

A next series of experiments addressed the effect of hyperosmotic shock (addition of $550 \mathrm{mM}$ sucrose) for 6 hours. As illustrated in Fig. 7, hyperosmotic shock was followed by a marked increase of the percentage of annexin-V-binding erythrocytes. The addition of volasertib $(0.5-1.5 \mu \mathrm{g} / \mathrm{ml})$ blunted the increase of the percentage of annexin-V-binding erythrocytes following hyperosmotic shock, an effect reaching statistical significance at 1 and $1.5 \mu \mathrm{g} / \mathrm{ml}$ volasertib. Again, even in the presence of volasertib, hyperosmotic shock significantly increased the percentage of phosphatidylserine exposing erythrocytes (Fig. 7). Volasertib thus partially blunted cell membrane scrambling following hyperosmotic shock.

Hyperosmotic shock was further followed by a marked decrease of forward scatter, reflecting erythrocyte shrinkage. The erythrocyte shrinkage following hyperosmotic shock was virtually identical in the absence and presence of volasertib $(0.5-1.5 \mu \mathrm{g} / \mathrm{ml}$ ) (Fig. 8). Accordingly, volasertib did not significantly interfere with the effect of hyperosmotic shock on erythrocyte volume. 


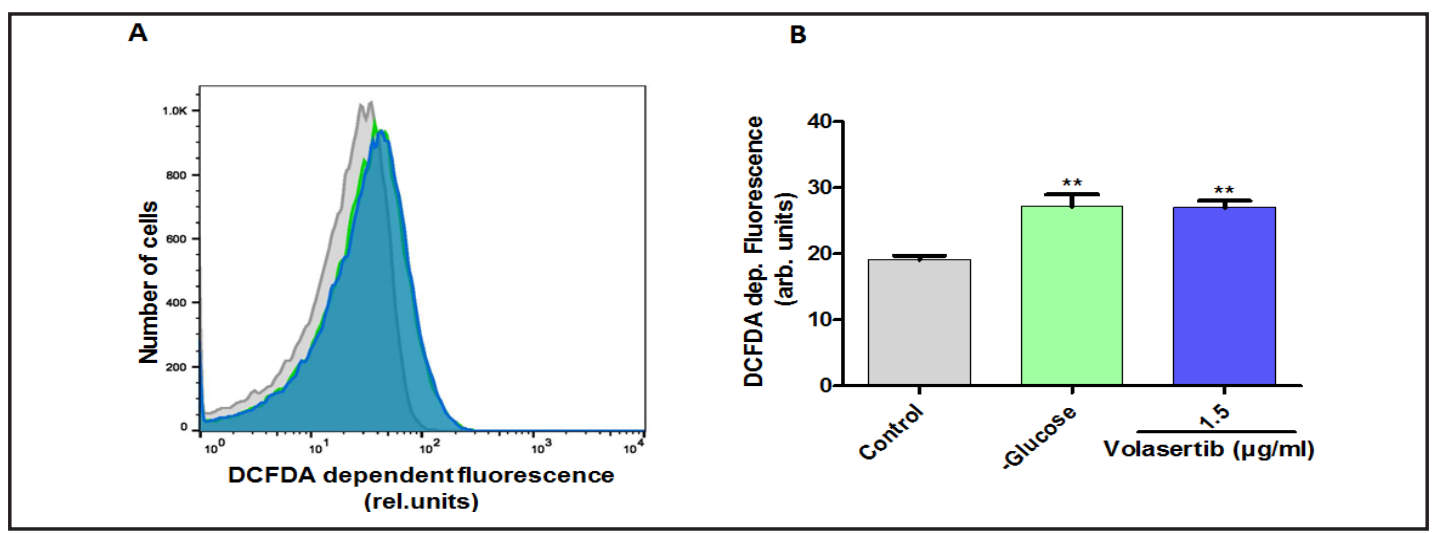

Fig. 6. Volasertib sensitivity of reactive oxygen species following energy depletion. A. Original histograms of DCFDA fluorescence reflecting reactive oxygen species in erythrocytes following exposure for 48 hours to glucose containing Ringer solution (grey areas), Ringer solution without glucose (green areas) and Ringer solution without glucose and presence of volasertib $(1.5 \mu \mathrm{g} / \mathrm{ml}$ ) (blue areas). B. Arithmetic means \pm SEM $(n=5)$ of DCFDA fluorescence in erythrocytes following a 48 hours treatment with Ringer solution with glucose (grey bar) or without glucose in the absence (green bar) and presence (blue bars) of volasertib (1.5 $\mu \mathrm{g} / \mathrm{ml}){ }^{* *}(\mathrm{p}<0.01)$ indicates significant difference from the presence of glucose.

A

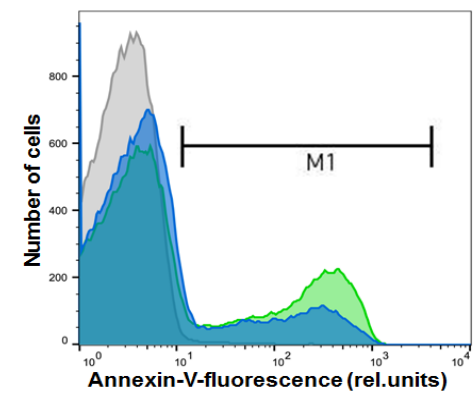

B

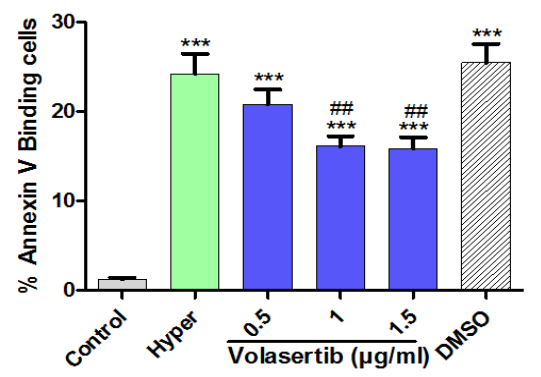

Fig. 7. Volasertib sensitivity of phosphatidylserine exposure following hyperosmotic shock. A. Original histograms of annexin-V-binding of erythrocytes following exposure for 6 hours to isotonic Ringer solution (grey area), or hypertonic Ringer solution (550 mM sucrose added) in absence (green areas) or presence (blue areas) of volasertib $(1.5 \mu \mathrm{g} / \mathrm{ml})$. B. Arithmetic means \pm SEM $(\mathrm{n}=10)$ of the percentage of annexinV-binding erythrocytes after a 6 hours treatment with isotonic Ringer solution (grey bar), or hypertonic Ringer solution (550 mM sucrose added) in the absence (green bar) and presence (blue bars) of volasertib $(0.5-1.5 \mu \mathrm{g} / \mathrm{ml})$. Striped bar is in presence of tert-butylhydroperoxide and DMSO. ${ }^{* * *}(\mathrm{p}<0.001)$ indicates significant difference from isotonic Ringer, \#\#(p<0.01) indicates significant difference from the absence of volasertib (ANOVA).

A next series of experiments addressed the effect of oxidative stress due to addition of 0.3 $\mathrm{mM}$ tert-butylhydroperoxide ( $\mathrm{tBOOH})$ for 50 minutes. As illustrated in Fig. 9, oxidative stress was followed by a marked increase of the percentage of annexin-V-binding erythrocytes. The addition of volasertib $(0.5-1.5 \mu \mathrm{g} / \mathrm{ml})$ did not significantly interfere with the increase of the percentage of annexin-V-binding erythrocytes following oxidative stress. Instead, oxidative stress significantly increased the percentage of phosphatidylserine exposing erythrocytes both, in the absence and presence of volasertib (Fig. 9).

Oxidative stress was further followed by a marked decrease of forward scatter, reflecting erythrocyte shrinkage. The erythrocyte shrinkage following oxidative stress was virtually 


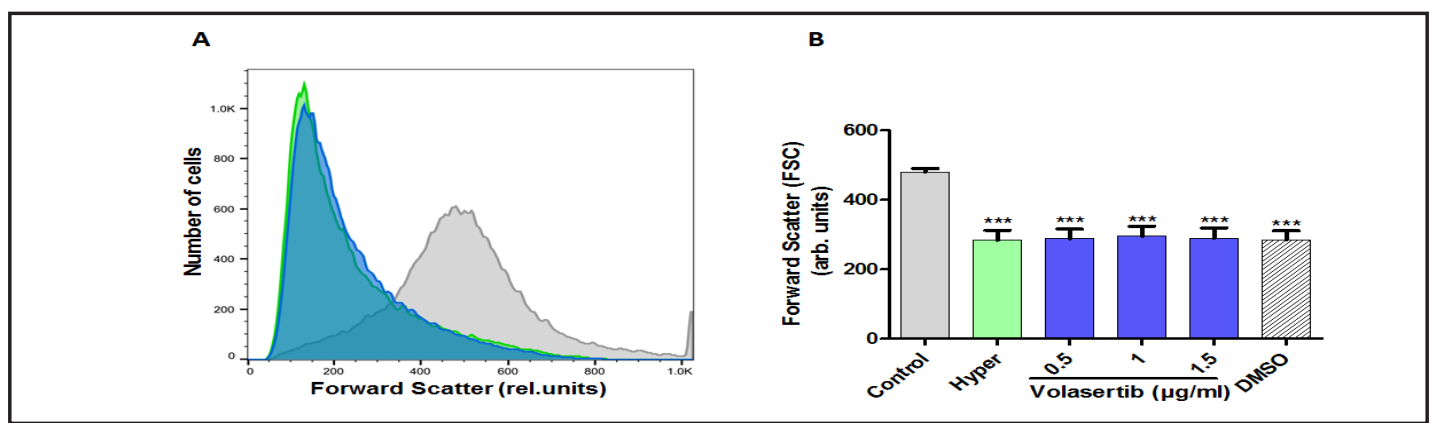

Fig. 8. Volasertib sensitivity of erythrocyte shrinkage following hyperosmotic shock. A. Original histograms of erythrocyte forward scatter following exposure for 6 hours to isotonic Ringer solution (grey area), or hypertonic Ringer solution (550 mM sucrose added) in absence (green areas) or presence (blue areas) of volasertib $(1.5 \mu \mathrm{g} / \mathrm{ml})$. B. Arithmetic means \pm SEM $(\mathrm{n}=10)$ of erythrocyte forward scatter after a 6 hours treatment with isotonic Ringer solution (grey bar), or hypertonic Ringer solution (550 mM sucrose added) in the absence (green bar) and presence (blue bars) of volasertib (0.5-1.5 $\mu \mathrm{g} / \mathrm{ml})$. Striped bar is in presence of tert-butylhydroperoxide and DMSO. ${ }^{* * *}(\mathrm{p}<0.001)$ indicates significant difference from isotonic Ringer (ANOVA).

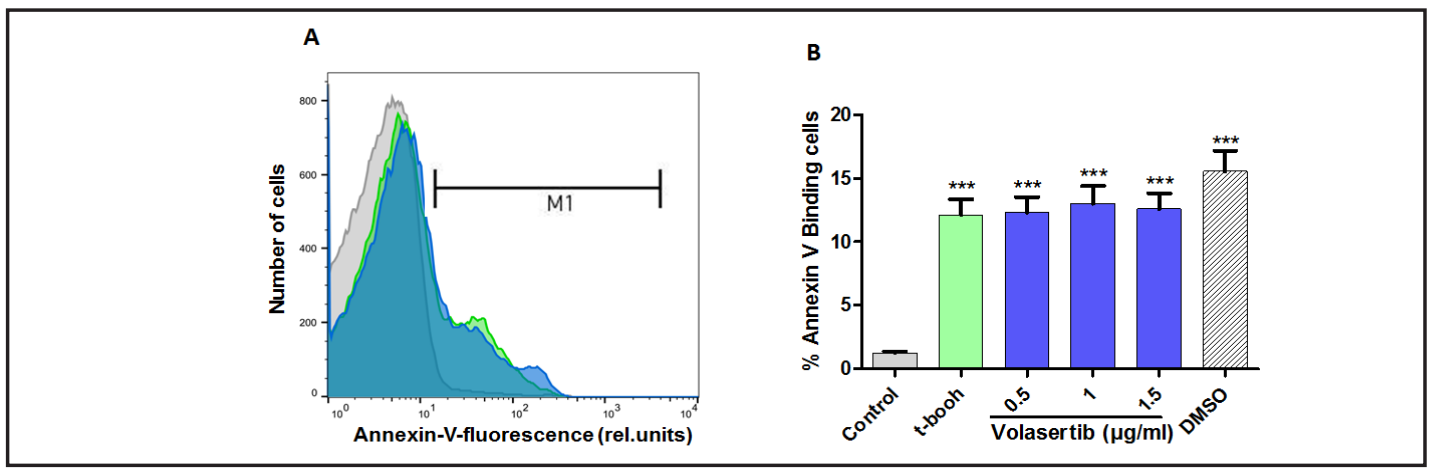

Fig. 9. Volasertib sensitivity of phosphatidylserine exposure following oxidative stress. A. Original histograms of annexin-V-binding of erythrocytes following exposure for $50 \mathrm{~min}$ to Ringer solution without tertbutylhydroperoxide (grey area), or Ringer solution with tert-butylhydroperoxide $(0.3 \mathrm{mM})$ and absence (green areas) or presence (blue areas) of volasertib $(1.5 \mu \mathrm{g} / \mathrm{ml})$. B. Arithmetic means \pm SEM $(\mathrm{n}=15)$ of the percentage of annexin-V-binding erythrocytes after a 50 min treatment with Ringer solution without tertbutylhydroperoxide (grey bar) or with tert-butylhydroperoxide $(0.3 \mathrm{mM})$ in the absence (green bar) and presence (blue bars) of volasertib $(0.5-1.5 \mu \mathrm{g} / \mathrm{ml})$. Striped bar is in presence of tert-butylhydroperoxide and DMSO. ${ }^{* * *}(\mathrm{p}<0.001)$ indicates significant difference from the absence of tert-butylhydroperoxide (ANOVA).

identical in the absence and presence of volasertib (0.5-1.5 $\mu \mathrm{g} / \mathrm{ml})$. Accordingly, volasertib did not significantly interfere with the effect of oxidative stress on erythrocyte volume (Fig. $10)$.

A next series of experiments explored the effect of $\mathrm{Ca}^{2+}$ entry, which was achieved by a $60 \mathrm{~min}$ exposure of erythrocytes to $\mathrm{Ca}^{2+}$ ionophore ionomycn $(1 \mu \mathrm{M})$. As illustrated in Fig. 11, exposure of the erythrocytes for 60 minutes to $1 \mu \mathrm{M}$ ionomycin was followed by a sharp increase of the percentage of annexin-V-binding erythrocytes. The effect tended to be slightly blunted by volasertib, an effect, however, not reaching statistical significance. Instead, even in the presence of volasertib, ionomycin significantly increased the percentage of phosphatidylserine exposing erythrocytes (Fig. 11).

Exposure of the erythrocytes for 60 minutes to $1 \mu \mathrm{M}$ ionomycin was followed by a sharp decrease of forward scatter (Fig. 12). The cell shrinkage was not significantly modified by volasertib (Fig. 12). 


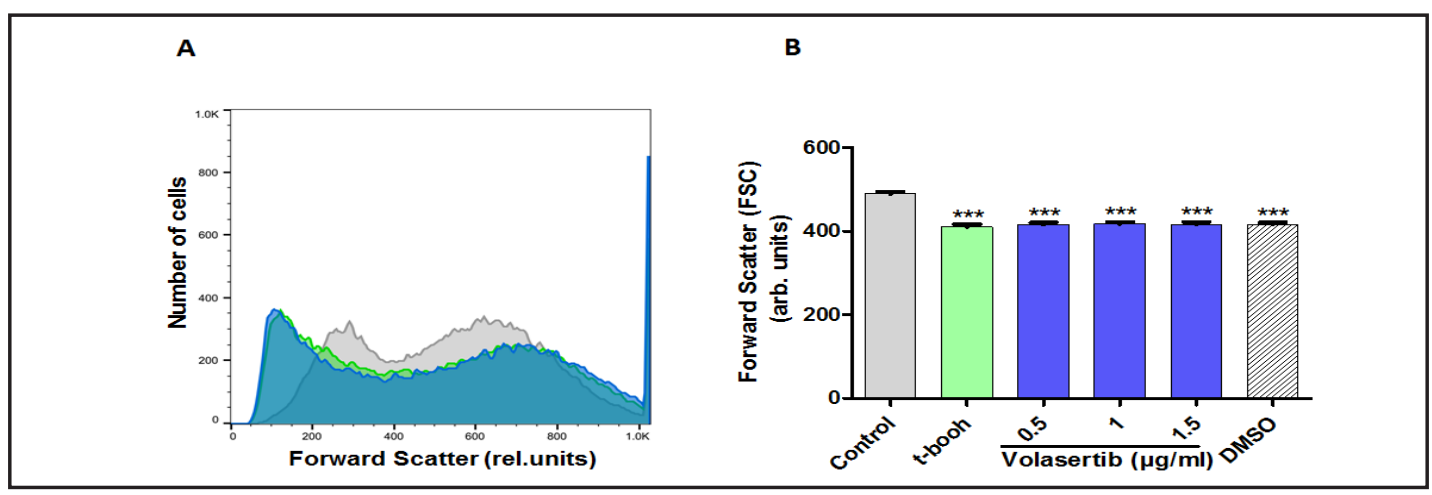

Fig. 10. Volasertib sensitivity of erythrocyte shrinkage following oxidative stress. A. Original histograms of erythrocyte forward scatter following exposure for $50 \mathrm{~min}$ to Ringer solution without tert-butylhydroperoxide (grey area), or Ringer solution with tert-butylhydroperoxide $(0.3 \mathrm{mM})$ and absence (green areas) or presence (blue areas) of volasertib $(1.5 \mu \mathrm{g} / \mathrm{ml})$. B. Arithmetic means \pm SEM $(\mathrm{n}=15)$ of erythrocyte forward scatter after a 50 min treatment with Ringer solution without tert-butylhydroperoxide (grey bar) or with tert-butylhydroperoxide $(0.3 \mathrm{mM})$ in the absence (green bar) and presence (blue bars) of volasertib (0.5-1.5 $\mu \mathrm{g} / \mathrm{ml})$. Striped bar is in presence of tert-butylhydroperoxide and DMSO. ${ }^{* * *}(\mathrm{p}<0.001)$ indicates significant difference from absence of tert-butylhydroperoxide (ANOVA).

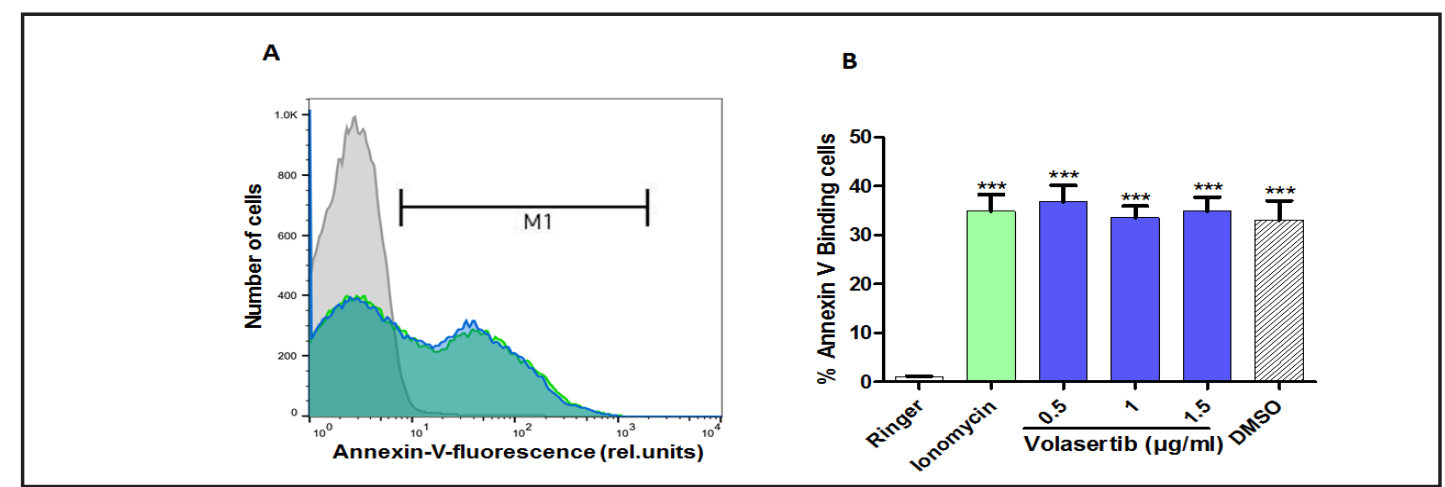

Fig. 11. Volasertib sensitivity of phosphatidylserine exposure following $\mathrm{Ca}^{2+}$ loading. A. Original histograms of annexin-V-binding of erythrocytes following exposure for $60 \mathrm{~min}$ to Ringer solution without $\mathrm{Ca}^{2+}$ ionophore ionomycin (grey area), or Ringer solution with ionomycin $(1 \mu \mathrm{M})$ and absence (green areas) or presence (blue areas) of volasertib $(1.5 \mu \mathrm{g} / \mathrm{ml})$. B. Arithmetic means \pm SEM $(n=10)$ of the percentage of annexin-V-binding erythrocytes after a $60 \mathrm{~min}$ treatment with Ringer solution without ionomycin (grey bar) or with ionomycin $(1 \mu \mathrm{M})$ in the absence (green bar) and presence (blue bars) of volasertib (0.5-1.5 $\mu \mathrm{g} / \mathrm{ml})$. Striped bar is in presence of ionomycin and DMSO. ${ }^{* * *}(\mathrm{p}<0.001)$ indicates significant difference from the absence of ionomycin (ANOVA).

\section{Discussion}

The present observations reveal a novel, unexpected effect of volasertib on erythrocyte cell membrane scrambling, which is a hallmark of eryptosis, the suicidal erythrocyte death. Treatment with volasertib alone did not significantly modify annexin-V-binding or forward scatter, but volasertib significantly blunted the stimulating effect of energy depletion and hyperosmotic shock on cell membrane scrambling. The volasertib concentrations required for this effect were in the range of concentrations (up to $1.45 \mu \mathrm{g} / \mathrm{ml}$ ) encountered in the plasma of patients [21]. Volasertib did not significantly interfere with the stimulating effect of oxidative stress and ionomycin on cell membrane scrambling and did not significantly interfere with the cell shrinkage following energy depletion, hyperosmotic shock, oxidative stress and ionomycin. 


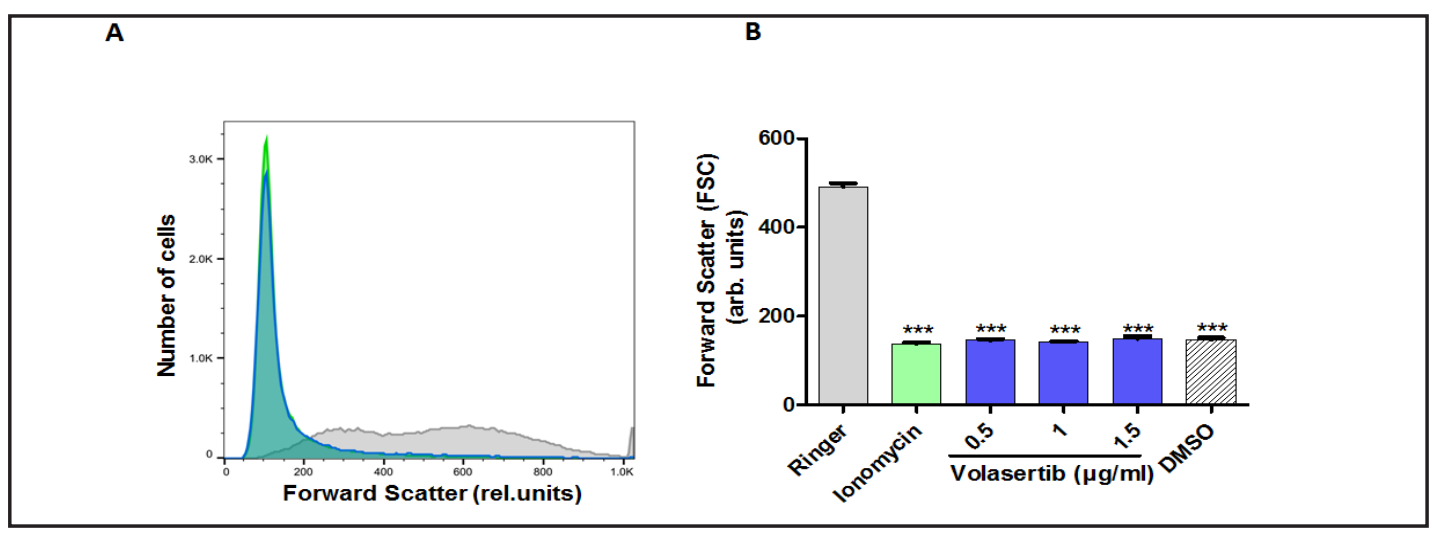

Fig. 12. Volasertib sensitivity of erythrocyte shrinkage following $\mathrm{Ca}^{2+}$ loading. A. Original histograms of erythrocyte forward scatter following exposure for $60 \mathrm{~min}$ to Ringer solution without ionomycin (grey area), or Ringer solution with ionomycin $(1 \mu \mathrm{M})$ and absence (green areas) or presence (blue areas) of volasertib $(1.5 \mu \mathrm{g} / \mathrm{ml})$. B. Arithmetic means \pm SEM $(\mathrm{n}=10)$ of erythrocyte forward scatter after a $60 \mathrm{~min}$ treatment with Ringer solution without ionomycin (grey bar) or with ionomycin $(1 \mu \mathrm{M})$ in the absence (green bar) and presence (blue bars) of volasertib $(0.5-1.5 \mu \mathrm{g} / \mathrm{ml})$. Striped bar is in presence of ionomycin and DMSO. ${ }^{* *}(\mathrm{p}<0.001)$ indicates significant difference from the absence of ionomycin (ANOVA).

The failure of volasertib to interfere with cell shrinkage could be explained by its inability to interfere with increase of cytosolic $\mathrm{Ca}^{2+}$ activity $\left(\left[\mathrm{Ca}^{2+}\right]_{\mathrm{i}}\right)$. An increase of $\left[\mathrm{Ca}^{2+}\right]_{\mathrm{i}}$ activates $\mathrm{Ca}^{2+}$ sensitive $\mathrm{K}^{+}$channels leading to $\mathrm{K}^{+}$exit, cell membrane hyperpolarization, $\mathrm{Cl}^{-}$exit and thus cellular loss of $\mathrm{KCl}$ with water [22].

The inhibitory effect of volasertib on cell membrane scrambling following energy depletion and hyperosmotic shock contrasts the stimulating effect of volasertib on apoptosis of nucleated cells, as shown here for K562 cells. While apoptosis and eryptosis share the eventual stimulation of cell membrane scrambling, the signaling triggering cell membrane scrambling differs considerably $[22,101]$. Along those lines, apoptosis following inhibition of polo-like kinases may involve mitochondria [102], which are absent in mature erythrocytes. In view of the stimulation of tumor cell death and the simultaneous protection against eryptosis of energy or shrunken erythrocytes, volasertib may be particularly useful in the treatment of malignancies associated with anemia [103].

The present study did not uncover the signaling involved in the effect of volasertib on cell membrane scrambling following energy depletion and hyperosmotic shock. As shown for energy depletion, volasertib did not significantly interfere with the increase of cytosolic $\mathrm{Ca}^{2+}$ activity and did not modify ceramide formation. In theory, eryptosis could involve Pololike kinase 1 (Plk1), wich is specifically inhibited by volasertib [1-10]. However, the effects of volasertib are not restricted to the polo-like kinase 1 (Plk1) isoform but the substance inhibits, albeit to a lesser extent, the isoforms Plk2 and Plk3 [8]. Moreover, other effects unrelated to Polo-like kinases cannot be ruled out. Further experimental effort is required to identify the mechanisms accomplishing the inhibitory effect of volasertib on eryptosis following energy depletion and hyperosmotic shock. Moreover, additional analysis may be required to understand why volasertib is effective following energy depletion and hyperosmotic shock, but not following oxidative stress and ionomycin. The discrepancy points to volasertib sensitive signaling triggering cell membrane scrambling, which is shared by energy depletion and hyperosmotic shock but not by oxidative stress and $\mathrm{Ca}^{2+}$ overload.

Whatever mechanism involved, volasertib is inhibiting rather than stimulating erythrocyte cell membrane scrambling. The observed enhanced incidence of anemia in volasertib-combination treatments may be attributed to the effects of the combined drug. Alternatively, volasertib triggers apoptosis of progenitor cells thus compromizing formation of new erythrocytes. If so, administration of the drug should decrease reticulocyte numbers in circulating blood. To the best of our knowledge, nothing is known about an 


\section{Cellular Physiology Cell Physiol Biochem 2017;43:1472-1486

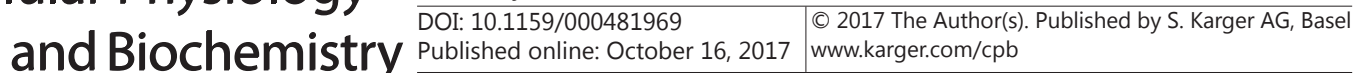 \\ Al Mamun Bhuyan et al.: Volasertib-Induced Eryptosis}

effect of volasertib on reticulocytes. In any case, inhibition of eryptosis counteracts anemia. Phosphatidylserine exposing erythrocytes are rapidly cleared from circulating blood and eryptosis leads to anemia as soon as the loss of eryptotic erythrocytes outcasts the formation of new erythrocytes by erythropoiesis [22].

As volasertib did not interfere with cell shrinkage, it presumably does not foster hemolysis. Hemoglobin released following hemolysis may otherwise pass the renal glomerular filter, precipitate in the acidic lumen of renal tubules, occlude nephrons and may thus lead to renal failure [104].

As phosphatidylserine exposing erythrocytes further adhere to the vascular wall [105], stimulate blood clotting/thrombosis [106-108], and interfere with microcirculation [25, 106, 109-112], the inhibition of eryptosis may decrease cardiovascular events in tumor patients.

In conclusion, volasertib inhibits erythrocyte cell membrane scrambling following energy depletion and hyperosmotic shock and thus rather counteracts suicidal erythrocyte death and development of anemia.

\section{Acknowledgements}

The authors acknowledge the meticulous preparation of the manuscript by Lejla Subasic. The study was supported by the Deutsche Forschungsgemeinschaft and Open Access Publishing Fund of Tuebingen University.

\section{Disclosure Statement}

The authors of this manuscript state that they have no conflicts of interest to declare.

\section{References}

1 Gutteridge RE, Ndiaye MA, Liu X, Ahmad N: Plk1 Inhibitors in Cancer Therapy: From Laboratory to Clinics. Mol Cancer Ther 2016;15:1427-1435.

-2 Van den Bossche J, Lardon F, Deschoolmeester V, De Pauw I, Vermorken JB, Specenier P, Pauwels P, Peeters M, Wouters A: Spotlight on Volasertib: Preclinical and Clinical Evaluation of a Promising Plk1 Inhibitor. Med Res Rev 2016;36:749-786.

-3 Talati C, Griffiths EA, Wetzler M, Wang ES: Polo-like kinase inhibitors in hematologic malignancies. Crit Rev Oncol Hematol 2016;98:200-210.

-4 Prochazkova I, Vojtesek B: [Polo-like Kinase 1 as a Target for Anti-tumor Therapy]. Klin Onkol 2015;28 Suppl 2:2s32-39.

5 Liu X: Targeting Polo-Like Kinases: A Promising Therapeutic Approach for Cancer Treatment. Transl Oncol 2015;8:185-195.

6 Helmke C, Becker S, Strebhardt K: The role of Plk3 in oncogenesis. Oncogene 2016;35:135-147.

7 Brandwein JM: Targeting polo-like kinase 1 in acute myeloid leukemia. Ther Adv Hematol 2015;6:80-87.

8 Janning M, Fiedler W: Volasertib for the treatment of acute myeloid leukemia: a review of preclinical and clinical development. Future Oncol 2014;10:1157-1165.

9 Yim H: Current clinical trials with polo-like kinase 1 inhibitors in solid tumors. Anticancer Drugs 2013;24:999-1006.

10 Schoffski P: Polo-like kinase (PLK) inhibitors in preclinical and early clinical development in oncology. Oncologist 2009;14:559-570.

11 Gjertsen BT, Schoffski P: Discovery and development of the Polo-like kinase inhibitor volasertib in cancer therapy. Leukemia 2015;29:11-19.

12 Awada A, Dumez H, Aftimos PG, Costermans J, Bartholomeus S, Forceville K, Berghmans T, Meeus MA, Cescutti J, Munzert G, Pilz K, Liu D, Schoffski P: Phase I trial of volasertib, a Polo-like kinase inhibitor, plus platinum agents in solid tumors: safety, pharmacokinetics and activity. Invest New Drugs 2015;33:611620.

13 Stadler WM, Vaughn DJ, Sonpavde G, Vogelzang NJ, Tagawa ST, Petrylak DP, Rosen P, Lin CC, Mahoney J, Modi S, Lee P, Ernstoff MS, Su WC, Spira A, Pilz K, Vinisko R, Schloss C, Fritsch H, Zhao C, Carducci MA: An open-label, single-arm, phase 2 trial of the Polo-like kinase inhibitor volasertib (BI 6727) in patients with locally advanced or metastatic urothelial cancer. Cancer 2014;120:976-982. 


\section{Cellular Physiology Cell Physiol Biochem 2017;43:1472-1486 \begin{tabular}{ll|l} 
and Biochemistry Published online: October 16, 2017 & $\begin{array}{l}\text { (C) } 2017 \text { The Author(s). Published by S. Karger AG, Basel } \\
\text { www.karger.com/cpb }\end{array}$
\end{tabular}}

Al Mamun Bhuyan et al.: Volasertib-Induced Eryptosis

14 Lin CC, Su WC, Yen CJ, Hsu CH, Su WP, Yeh KH, Lu YS, Cheng AL, Huang DC, Fritsch H, Voss F, Taube T, Yang JC: A phase I study of two dosing schedules of volasertib (BI 6727), an intravenous polo-like kinase inhibitor, in patients with advanced solid malignancies. Br J Cancer 2014;110:2434-2440.

15 Shafer D, Grant S: Update on rational targeted therapy in AML. Blood Rev 2016;30:275-283.

-16 Podoltsev NA, Stahl M, Zeidan AM, Gore SD: Selecting initial treatment of acute myeloid leukaemia in older adults. Blood Rev 2017;31:43-62.

17 Hao Z, Kota V: Volasertib for AML: clinical use and patient consideration. Onco Targets Ther 2015;8:17611771.

18 Erba HP: Finding the optimal combination therapy for the treatment of newly diagnosed AML in older patients unfit for intensive therapy. Leuk Res 2015;39:183-191.

19 Sasine JP, Schiller GJ: Emerging strategies for high-risk and relapsed/refractory acute myeloid leukemia: novel agents and approaches currently in clinical trials. Blood Rev 2015;29:1-9.

20 Montalban-Bravo G, Garcia-Manero G: Novel drugs for older patients with acute myeloid leukemia. Leukemia 2015;29:760-769.

-21 Schoffski P, Awada A, Dumez H, Gil T, Bartholomeus S, Wolter P, Taton M, Fritsch H, Glomb P, Munzert G: A phase I, dose-escalation study of the novel Polo-like kinase inhibitor volasertib (BI 6727) in patients with advanced solid tumours. Eur J Cancer 2012;48:179-186.

22 Lang E, Lang F: Mechanisms and pathophysiological significance of eryptosis, the suicidal erythrocyte death. Semin Cell Dev Biol 2015;39:35-42.

23 Dermaku-Sopjani M, Abazi S, Faggio C, Kolgeci J, Sopjani M: AMPK-sensitive cellular transport. J Biochem 2014;155:147-158.

24 Lang PA, Kaiser S, Myssina S, Wieder T, Lang F, Huber SM: Role of Ca2+-activated K+ channels in human erythrocyte apoptosis. Am J Physiol Cell Physiol 2003;285:C1553-C1560.

25 Abed M, Towhid ST, Mia S, Pakladok T, Alesutan I, Borst O, Gawaz M, Gulbins E, Lang F: Sphingomyelinaseinduced adhesion of eryptotic erythrocytes to endothelial cells. Am J Physiol Cell Physiol 2012;303:C991999.

26 Lau IP, Chen H, Wang J, Ong HC, Leung KC, Ho HP, Kong SK: In vitro effect of CTAB- and PEG-coated gold nanorods on the induction of eryptosis/erythroptosis in human erythrocytes. Nanotoxicology 2012;6:847856.

27 Maellaro E, Leoncini S, Moretti D, Del Bello B, Tanganelli I, De Felice C, Ciccoli L: Erythrocyte caspase-3 activation and oxidative imbalance in erythrocytes and in plasma of type 2 diabetic patients. Acta Diabetol 2013;50:489-495.

-28 Bissinger R, Lang E, Ghashghaeinia M, Singh Y, Zelenak C, Fehrenbacher B, Honisch S, Chen H, Fakhri H, Umbach AT, Liu G, Rexhepaj R, Liu G, Schaller M, Mack AF, Lupescu A, Birnbaumer L, Lang F, Qadri SM: Blunted apoptosis of erythrocytes in mice deficient in the heterotrimeric G-protein subunit Galphai2. Sci Rep 2016;6:30925.

29 Lang E, Bissinger R, Fajol A, Salker MS, Singh Y, Zelenak C, Ghashghaeinia M, Gu S, Jilani K, Lupescu A, Reyskens KM, Ackermann TF, Foller M, Schleicher E, Sheffield WP, Arthur JS, Lang F, Qadri SM: Accelerated apoptotic death and in vivo turnover of erythrocytes in mice lacking functional mitogen- and stressactivated kinase MSK1/2. Sci Rep 2015;5:17316.

-30 Alzoubi K, Egler J, Abed M, Lang F: Enhanced Eryptosis Following Auranofin Exposure. Cell Physiol Biochem 2015;37:1018-1028.

-31 Bissinger R, Bouguerra G, Stockinger K, Abbes S, Lang F: Triggering of Suicidal Erythrocyte Death by Topotecan. Cell Physiol Biochem 2015;37:1607-1618.

-32 Bouguerra G, Aljanadi O, Bissinger R, Abbes S, Lang F: Embelin-Induced Phosphatidylserine Translocation in the Erythrocyte Cell Membrane. Cell Physiol Biochem 2015;37:1629-1640.

33 Briglia M, Fazio A, Faggio C, Laufer S, Alzoubi K, Lang F: Triggering of Suicidal Erythrocyte Death by Ruxolitinib. Cell Physiol Biochem 2015;37:768-778.

34 Briglia M, Fazio A, Signoretto E, Faggio C, Lang F: Edelfosine Induced Suicidal Death of Human Erythrocytes. Cell Physiol Biochem 2015;37:2221-2230.

-35 Calabro S, Alzoubi K, Faggio C, Laufer S, Lang F: Triggering of Suicidal Erythrocyte Death Following Boswellic Acid Exposure. Cell Physiol Biochem 2015;37:131-142.

-36 Egler J, Lang F: Licochalcone A Induced Suicidal Death of Human Erythrocytes. Cell Physiol Biochem 2015;37:2060-2070.

37 Fazio A, Briglia M, Faggio C, Alzoubi K, Lang F: Stimulation of Suicidal Erythrocyte Death by Garcinol. Cell Physiol Biochem 2015;37:805-815. 


\section{Cellular Physiology Cell Physiol Biochem 2017;43:1472-1486

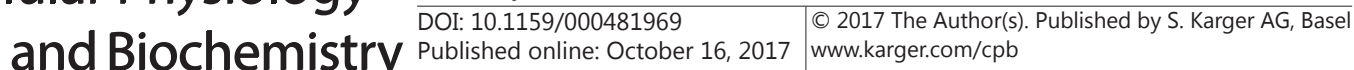

Al Mamun Bhuyan et al.: Volasertib-Induced Eryptosis

-38 Lang E, Jilani K, Bissinger R, Rexhepaj R, Zelenak C, Lupescu A, Lang F, Qadri SM: Vitamin D-Rich Diet in Mice Modulates Erythrocyte Survival. Kidney Blood Press Res 2015;40:403-412.

-39 Officioso A, Alzoubi K, Manna C, Lang F: Clofazimine Induced Suicidal Death of Human Erythrocytes. Cell Physiol Biochem 2015;37:331-341.

40 Peter T, Bissinger R, Enkel S, Alzoubi K, Oswald G, Lang F: Programmed erythrocyte death following in vitro Treosulfan treatment. Cell Physiol Biochem 2015;35:1372-1380.

41 Stockinger K, Bissinger R, Bouguerra G, Abbes S, Lang F: Enhanced Eryptosis Following Exposure to Carnosic Acid. Cell Physiol Biochem 2015;37:1779-1791.

42 Waibel S, Bissinger R, Bouguerra G, Abbes S, Lang F: Saquinavir Induced Suicidal Death of Human Erythrocytes. Cell Physiol Biochem 2015;37:1973-1982.

43 Zierle J, Bissinger R, Egler J, Lang F: Lapatinib Induced Suicidal Death of Human Erythrocytes. Cell Physiol Biochem 2015;37:2275-2287.

44 Bissinger R, Waibel S, Bouguerra G, Al Mamun Bhuyan A, Abbes S, Lang F: Enhanced Eryptosis Following Exposure to Lopinavir. Cell Physiol Biochem 2015;37:2486-2495.

45 Briglia M, Fazio A, Faggio C, Lang F: Triggering of Suicidal Erythrocyte Death by Zosuquidar. Cell Physiol Biochem 2015;37:2355-2365.

-46 Fazio A, Briglia M, Faggio C, Alzoubi K, Lang F: Oxaliplatin Induced Suicidal Death of Human Erythrocytes. Cell Physiol Biochem 2015;37:2393-2404.

47 Macczak A, Cyrkler M, Bukowska B, Michalowicz J: Eryptosis-inducing activity of bisphenol A and its analogs in human red blood cells (in vitro study). J Hazard Mater 2016;307:328-335.

48 Officioso A, Manna C, Alzoubi K, Lang F: Bromfenvinphos induced suicidal death of human erythrocytes. Pestic Biochem Physiol 2016;126:58-63.

49 Qadri SM, Donkor DA, Bhakta V, Eltringham-Smith LJ, Dwivedi DJ, Moore JC, Pepler L, Ivetic N, Nazi I, Fox-Robichaud AE, Liaw PC, Sheffield WP: Phosphatidylserine externalization and procoagulant activation of erythrocytes induced by Pseudomonas aeruginosa virulence factor pyocyanin. J Cell Mol Med 2016;10.1111/jcmm.12778

50 Zierle J, Bissinger R, Bouguerra G, Abbes S, Lang F: Triggering of Suicidal Erythrocyte Death by Regorafenib. Cell Physiol Biochem 2016;38:160-172.

51 Pagano M, Faggio C: The use of erythrocyte fragility to assess xenobiotic cytotoxicity. Cell Biochem Funct 2015;33:351-355.

52 Al Mamun Bhuyan A, Signoretto E, Bissinger R, Lang F: Enhanced Eryptosis Following Exposure to Dolutegravir. Cell Physiol Biochem 2016;39:639-650.

-53 Al Mamun Bhuyan A, Signoretto E, Lang F: Triggering of Suicidal Erythrocyte Death by Psammaplin A. Cell Physiol Biochem 2016;39:908-918.

54 Almasry M, Jemaa M, Mischitelli M, Faggio C, Lang F: Stimulation of Suicidal Erythrocyte Death by Phosphatase Inhibitor Calyculin A. Cell Physiol Biochem 2016;40:163-171.

-55 Bissinger R, Bhuyan AA, Signoretto E, Lang F: Stimulating Effect of Elvitegravir on Suicidal Erythrocyte Death. Cell Physiol Biochem 2016;38:1111-1120.

-56 Egler J, Zierle J, Lang F: Stimulating Effect of Manumycin A on Suicidal Erythrocyte Death. Cell Physiol Biochem 2016;38:1147-1156.

57 Mischitelli M, Jemaa M, Almasry M, Faggio C, Lang F: Stimulation of Erythrocyte Cell Membrane Scrambling by Quinine. Cell Physiol Biochem 2016;40:657-667.

58 Mischitelli M, Jemaa M, Almasry M, Faggio C, Lang F: Stimulation of Suicidal Erythrocyte Death by Rottlerin. Cell Physiol Biochem 2016;40:558-566.

59 Mischitelli M, Jemaa M, Almasry M, Faggio C, Lang F: Triggering of Suicidal Erythrocyte Death by Fascaplysin. Cell Physiol Biochem 2016;39:1638-1647.

60 Mischitelli M, Jemaa M, Almasry M, Faggio C, Lang F: Ca2+ Entry, Oxidative Stress, Ceramide and Suicidal Erythrocyte Death Following Diosgenin Treatment. Cell Physiol Biochem 2016;39:1626-1637.

61 Mischitelli M, Jemaa M, Almasry M, Faggio C, Lang F: Triggering of Erythrocyte Cell Membrane Scrambling by Emodin. Cell Physiol Biochem 2016;40:91-103.

62 Peter T, Bissinger R, Lang F: Stimulation of Eryptosis by Caspofungin. Cell Physiol Biochem 2016;39:939949.

63 Peter T, Bissinger R, Liu G, Lang F: Anidulafungin-Induced Suicidal Erythrocyte Death. Cell Physiol Biochem 2016;38:2272-2284.

64 Peter T, Bissinger R, Signoretto E, Mack AF, Lang F: Micafungin-Induced Suicidal Erythrocyte Death. Cell Physiol Biochem 2016;39:584-595. 


\section{Cellular Physiology Cell Physiol Biochem 2017;43:1472-1486 \begin{tabular}{l|l} 
DOI: 10.1159/000481969 & $\begin{array}{l}\text { O 2017 The Author(s). Published by S. Karger AG, Basel } \\
\text { www.karger.com/cpb }\end{array}$
\end{tabular}}

Al Mamun Bhuyan et al.: Volasertib-Induced Eryptosis

65 Pretorius E, du Plooy JN, Bester J: A Comprehensive Review on Eryptosis. Cell Physiol Biochem 2016;39:1977-2000.

66 Shan F, Yang R, Ji T, Jiao F: Vitamin C Inhibits Aggravated Eryptosis by Hydrogen Peroxide in Glucose-6Phosphated Dehydrogenase Deficiency. Cell Physiol Biochem 2016;39:1453-1462.

67 Signoretto E, Honisch S, Briglia M, Faggio C, Castagna M, Lang F: Nocodazole Induced Suicidal Death of Human Erythrocytes. Cell Physiol Biochem 2016;38:379-392.

68 Signoretto E, Laufer SA, Lang F: Stimulating Effect of Sclareol on Suicidal Death of Human Erythrocytes. Cell Physiol Biochem 2016;39:554-564.

69 Signoretto E, Zierle J, Bissinger R, Castagna M, Bossi E, Lang F: Triggering of Suicidal Erythrocyte Death by Pazopanib. Cell Physiol Biochem 2016;38:926-938.

70 Wesseling MC, Wagner-Britz L, Huppert H, Hanf B, Hertz L, Nguyen DB, Bernhardt I: Phosphatidylserine Exposure in Human Red Blood Cells Depending on Cell Age. Cell Physiol Biochem 2016;38:1376-1390.

-71 Zierle J, Bissinger R, Lang F: Inhibition by Teriflunomide of Erythrocyte Cell Membrane Scrambling Following Energy Depletion, Oxidative Stress and Ionomycin. Cell Physiol Biochem 2016;39:1877-1890.

72 Bissinger R, Modicano P, Alzoubi K, Honisch S, Faggio C, Abed M, Lang F: Effect of saponin on erythrocytes. Int J Hematol 2014;100:51-59.

73 Bissinger R, Modicano P, Frauenfeld L, Lang E, Jacobi J, Faggio C, Lang F: Estramustine-induced suicidal erythrocyte death. Cell Physiol Biochem 2013;32:1426-1436.

74 Voelkl J, Alzoubi K, Mamar AK, Ahmed MS, Abed M, Lang F: Stimulation of suicidal erythrocyte death by increased extracellular phosphate concentrations. Kidney Blood Press Res 2013;38:42-51.

-75 Al Mamun Bhuyan A, Bissinger R, Cao H, Lang F: Triggering of Suicidal Erythrocyte Death by bexaroten. Cell Physiol Biochem 2016;in press.:

76 Bissinger R, Barking S, Alzoubi K, Liu G, Liu G, Lang F: Stimulation of Suicidal Erythrocyte Death by the Antimalarial Drug Mefloquine. Cell Physiol Biochem 2015;36:1395-1405.

77 Bissinger R, Bouguerra G, Al Mamun Bhuyan A, Waibel S, Abbes S, Lang F: Efavirenz Induced Suicidal Death of Human Erythrocytes. Cell Physiol Biochem 2015;37:2496-2507.

-78 Briglia M, Calabro S, Signoretto E, Alzoubi K, Laufer S, Faggio C, Lang F: Fucoxanthin Induced Suicidal Death of Human Erythrocytes. Cell Physiol Biochem 2015;37:2464-2475.

79 Faggio C, Alzoubi K, Calabro S, Lang F: Stimulation of suicidal erythrocyte death by PRIMA-1. Cell Physiol Biochem 2015;35:529-540.

80 Jemaa M, Mischitelli M, Fezai M, Almasry M, Faggio C, Lang F: Stimulation of Suicidal Erythrocyte Death by the CDC25 Inhibitor NSC-95397. Cell Physiol Biochem 2016;40:597-607.

-81 Lang E, Modicano P, Arnold M, Bissinger R, Faggio C, Abed M, Lang F: Effect of thioridazine on erythrocytes. Toxins (Basel) 2013;5:1918-1931.

82 Signoretto E, Bissinger R, Castagna M, Lang F: Stimulation of Eryptosis by Combretastatin A4 Phosphate Disodium (CA4P). Cell Physiol Biochem 2016;38:969-981.

83 Bouguerra G, Bissinger R, Abbes S, Lang F: Stimulation of Eryptosis by Narasin. Cell Physiol Biochem 2015;37:1807-1816.

-84 Abed M, Feger M, Alzoubi K, Pakladok T, Frauenfeld L, Geiger C, Towhid ST, Lang F: Sensitization of erythrocytes to suicidal erythrocyte death following water deprivation. Kidney Blood Press Res 2013;37:567-578.

85 Abed M, Artunc F, Alzoubi K, Honisch S, Baumann D, Foller M, Lang F: Suicidal erythrocyte death in endstage renal disease. J Mol Med (Berl) 2014;92:871-879.

-86 Ahmed MS, Langer H, Abed M, Voelkl J, Lang F: The uremic toxin acrolein promotes suicidal erythrocyte death. Kidney Blood Press Res 2013;37:158-167.

87 Polak-Jonkisz D, Purzyc L: Ca(2+) influx versus efflux during eryptosis in uremic erythrocytes. Blood Purif 2012;34:209-210; author reply 210.

-88 Calderon-Salinas JV, Munoz-Reyes EG, Guerrero-Romero JF, Rodriguez-Moran M, Bracho-Riquelme RL, Carrera-Gracia MA, Quintanar-Escorza MA: Eryptosis and oxidative damage in type 2 diabetic mellitus patients with chronic kidney disease. Mol Cell Biochem 2011;357:171-179.

89 Bissinger R, Artunc F, Qadri SM, Lang F: Reduced Erythrocyte Survival in Uremic Patients Under Hemodialysis or Peritoneal Dialysis. Kidney Blood Press Res 2016;41:966-977.

-90 Lang PA, Beringer O, Nicolay JP, Amon O, Kempe DS, Hermle T, Attanasio P, Akel A, Schafer R, Friedrich B, Risler T, Baur M, Olbricht CJ, Zimmerhackl LB, Zipfel PF, Wieder T, Lang F: Suicidal death of erythrocytes in recurrent hemolytic uremic syndrome. J Mol Med (Berl) 2006;84:378-388. 


\section{Cellular Physiology Cell Physiol Biochem 2017;43:1472-1486 \begin{tabular}{l|l|l} 
and Biochemistry Published online: October 16, 2017 & $\begin{array}{l}\text { (c) } 2017 \text { The Author(s). Published by S. Karger AG, Basel } \\
\text { www.karger.com/cpb }\end{array}$
\end{tabular}}

Al Mamun Bhuyan et al.: Volasertib-Induced Eryptosis

-91 Nicolay JP, Schneider J, Niemoeller OM, Artunc F, Portero-Otin M, Haik G, Jr., Thornalley PJ, Schleicher E, Wieder T, Lang F: Stimulation of suicidal erythrocyte death by methylglyoxal. Cell Physiol Biochem 2006;18:223-232.

92 Lang E, Pozdeev VI, Gatidis S, Qadri SM, Haussinger D, Kubitz R, Herebian D, Mayatepek E, Lang F, Lang KS, Lang PA: Bile Acid-Induced Suicidal Erythrocyte Death. Cell Physiol Biochem 2016;38:1500-1509.

-93 Lang E, Gatidis S, Freise NF, Bock H, Kubitz R, Lauermann C, Orth HM, Klindt C, Schuier M, Keitel V, Reich M, Liu G, Schmidt S, Xu HC, Qadri SM, Herebian D, Pandyra AA, Mayatepek E, Gulbins E, Lang F, Haussinger D, Lang KS, Foller M, Lang PA: Conjugated bilirubin triggers anemia by inducing erythrocyte death. Hepatology 2015;61:275-284.

-94 Bissinger R, Schumacher C, Qadri SM, Honisch S, Malik A, Gotz F, Kopp HG, Lang F: Enhanced eryptosis contributes to anemia in lung cancer patients. Oncotarget 2016;7:14002-14014.

$\$ 95$ Qadri SM, Mahmud H, Lang E, Gu S, Bobbala D, Zelenak C, Jilani K, Siegfried A, Foller M, Lang F: Enhanced suicidal erythrocyte death in mice carrying a loss-of-function mutation of the adenomatous polyposis coli gene. J Cell Mol Med 2012;16:1085-1093.

-96 Bissinger R, Kempe-Teufel DS, Honisch S, Qadri SM, Randrianarisoa E, Haring HU, Henes J, Lang F: Stimulated Suicidal Erythrocyte Death in Arteritis. Cell Physiol Biochem 2016;39:1068-1077.

\$7 Kempe DS, Akel A, Lang PA, Hermle T, Biswas R, Muresanu J, Friedrich B, Dreischer P, Wolz C, Schumacher U, Peschel A, Gotz F, Doring G, Wieder T, Gulbins E, Lang F: Suicidal erythrocyte death in sepsis. J Mol Med (Berl) 2007;85:273-281.

\$9 Lang PA, Schenck M, Nicolay JP, Becker JU, Kempe DS, Lupescu A, Koka S, Eisele K, Klarl BA, Rubben H, Schmid KW, Mann K, Hildenbrand S, Hefter H, Huber SM, Wieder T, Erhardt A, Haussinger D, Gulbins E, Lang F: Liver cell death and anemia in Wilson disease involve acid sphingomyelinase and ceramide. Nat Med 2007;13:164-170.

\$9 Lupescu A, Bissinger R, Goebel T, Salker MS, Alzoubi K, Liu G, Chirigiu L, Mack AF, Qadri SM, Lang F: Enhanced suicidal erythrocyte death contributing to anemia in the elderly. Cell Physiol Biochem 2015;36:773-783.

100 Lang E, Pozdeev VI, Xu HC, Shinde PV, Behnke K, Hamdam JM, Lehnert E, Scharf RE, Lang F, Haussinger D, Lang KS, Lang PA: Storage of Erythrocytes Induces Suicidal Erythrocyte Death. Cell Physiol Biochem 2016;39:668-676.

101 Kiraz Y, Adan A, Kartal Yandim M, Baran Y: Major apoptotic mechanisms and genes involved in apoptosis. Tumour Biol 2016;37:8471-8486.

102 Hugle M, Belz K, Fulda S: Identification of synthetic lethality of PLK1 inhibition and microtubuledestabilizing drugs. Cell Death Differ 2015;22:1946-1956.

103 Lang E, Bissinger R, Qadri SM, Lang F: Suicidal death of erythrocytes in cancer and its chemotherapy: A potential target in the treatment of tumor-associated anemia. Int J Cancer 2017;141:1522-1528.

104 Harrison HE, Bunting H, Ordway NK, Albrink WS: The Pathogenesis of the Renal Injury Produced in the Dog by Hemoglobin or Methemoglobin. J Exp Med 1947;86:339-356.

105 Borst O, Abed M, Alesutan I, Towhid ST, Qadri SM, Foller M, Gawaz M, Lang F: Dynamic adhesion of eryptotic erythrocytes to endothelial cells via CXCL16/SR-PSOX. Am J Physiol Cell Physiol 2012;302:C644-C651.

106 Andrews DA, Low PS: Role of red blood cells in thrombosis. Curr Opin Hematol 1999;6:76-82.

107 Chung SM, Bae ON, Lim KM, Noh JY, Lee MY, Jung YS, Chung JH: Lysophosphatidic acid induces thrombogenic activity through phosphatidylserine exposure and procoagulant microvesicle generation in human erythrocytes. Arterioscler Thromb Vasc Biol 2007;27:414-421.

108 Zwaal RF, Comfurius P, Bevers EM: Surface exposure of phosphatidylserine in pathological cells. Cell Mol Life Sci 2005;62:971-988.

109 Closse C, Dachary-Prigent J, Boisseau MR: Phosphatidylserine-related adhesion of human erythrocytes to vascular endothelium. Br J Haematol 1999;107:300-302.

110 Gallagher PG, Chang SH, Rettig MP, Neely JE, Hillery CA, Smith BD, Low PS: Altered erythrocyte endothelial adherence and membrane phospholipid asymmetry in hereditary hydrocytosis. Blood 2003;101:46254627.

111 Pandolfi A, Di Pietro N, Sirolli V, Giardinelli A, Di Silvestre S, Amoroso L, Di Tomo P, Capani F, Consoli A, Bonomini M: Mechanisms of uremic erythrocyte-induced adhesion of human monocytes to cultured endothelial cells. J Cell Physiol 2007;213:699-709.

112 Wood BL, Gibson DF, Tait JF: Increased erythrocyte phosphatidylserine exposure in sickle cell disease: flowcytometric measurement and clinical associations. Blood 1996;88:1873-1880. 